\title{
People-, Process- and Goal-Focused Leadership Behaviour: An Empirical Study in a Global Company
}

\author{
THANH HA-VIKSTRÖM \\ University of Vaasa, Finland \\ thanh.ha-vikström@student.uwasa.fi
}

\begin{abstract}
This study explores the focus of leadership behaviours that perceived and experienced by leaders in a multinational company. By using triangulation method including questionnaires, in-depth interviews and observations, we analyse the data collected from twenty managers across organisational levels. The results reveal the patterns of managerial behaviour in three key focus areas for success: people, process and goal. Directors and general managers are more people-focused than line managers, who in turn tend to be more process-focused. The research findings bridge the gap in the field and initiate a new normative leadership behaviour model (people-, process and goal-focused), which can be used to directly support leaders in enhancing their leadership skills as well as for recruitment or promotion purposes. The model can be utilized as an aid to organisations when developing training programs to support leaders in different types of organisations (for-profit or non-profit) to focus their development efforts on organizational success.
\end{abstract}

Key words: leadership, leadership behaviour, people-focused, process-focused, goal-focused https://doi.org/10.26493/1854-4231.12.75-103

\section{Introduction}

Today's business world is changing more rapidly and more dramatically than ever before. Changes are driven by, among other things, advanced technological innovation, globalization and hypercompetition. In order to deal with such a complex dynamic environment, business leaders must help their companies to adapt to rapid speed of change in order to ensure enduring organisational success. Business leaders, meanwhile, need to enhance employees' aspiration and activate their higher order needs through ethical, symbolic and helping behaviours (Bass et al. 2003; Antonakis and House 2014).

Despite agreement on the importance of leadership behaviour in business success, since 1940 it was becoming clear that there were 
two separate but related paths for thinking about leadership behaviours orientations. One path, the relationship/people-oriented behaviour (Fleishman 1957; Bass 1967; Fiedler and House 1988; Johannsen 2012); the second path, the task- or goal-oriented leadership behaviour (Fleishman 1953a; 1953b; Halpin 1954; Stogdill 1963; House 1971; Bass 1990; Griffin and Ebert 2010; Anzalone 2012); and the third path, non-relations-oriented and non-task-oriented, which is called laissez-faire or inactive leadership behaviours (Bass and Avolio 1995; 1997). Unrelated to these paths, De Jong and Den Hartog (2007) proposed that there are 13 relevant leadership behaviours including innovative role-modelling, stimulating knowledge diffusion, providing vision, providing resources, organizing feedback, monitoring, and consulting etc. (see table 1).

The key problem is that many various titles have been used to categorize the task-oriented leadership behaviours. For example, taskorientation can be referred to goal achieving (Cartwright and Zander 1960) or goal emphasizing (Bowers and Seashore 1966) or initiating structure (Hemphill 1950). Actually, some of them are similar and some of them are dissimilar. Furthermore, in terms of processoriented behaviours, even Harrington (2011) explains that if people are the heart of the organization, then processes represent the brain. This important path (business process-oriented leadership behaviour) as well as the combination of three paths: people, process and goal at the same time remains unexplored.

Based on above shortcoming, the aim of this study is to explore leadership behaviours as perceived or experienced by different levels of leaders/managers in a company, especially in three key focus areas: people, process, and goal. By relating directly to the real, practical experience of people in a business organization, we pursue to answer the following research question: how leadership behaviour is manifested across organisational levels.

As Srikumar Rao (2010), a TED Talk speaker and the author of Happiness at Work, has said:

We live in a world where what we (people) think of, what we invest in, is the outcome (goal). We define our life in the following way: here I am, here is where I want to go, these are the steps (process) I have to take in order to get from where I am to where I want to go, and if I succeed, life is wonderful. And if you don't succeed, still wonderful, because now you have a new starting point, and from that new starting point, you select another outcome and keep going. 


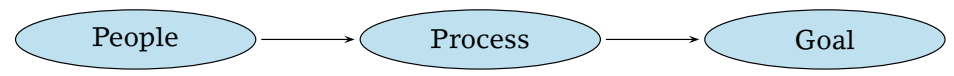

FIGURE 1 Essential Focus Areas for Leadership Behaviour

We use triangulation method, a combination of qualitative and quantitative approaches, comprising a questionnaire, in-depth interviews and observation to examine data collected from 20 female and male managers, $90 \%$ of whom were European, across different organisational levels: namely, directors, general managers and line managers. Each of them has an engineering or information technology background within a global company in Northern Europe (at the request of the studied company, its name will not be revealed).

This paper proceeds as follows. First, we briefly explain our conceptual framework. We then describe our methodology, the way in which we collected and analysed the data, as well as the validity and reliability of the work. We next provide details of our findings and present our evaluations. Finally, we conclude with a discussion of the findings, limitations and opportunities for further research.

\section{Conceptual Framework}

The conceptual framework for this research is constructed, not found. It incorporates different partial pieces that are borrowed from the leadership theories but 'the overall coherence, is something that we build, not something that exists ready-made' (Maxwell 2012). These varying theoretical perspectives are supposed to be useful and enrich our understanding of organisational phenomena (Hitt et al. 2007). Our conceptual framework are constructed from four main sources (see Maxwell 2012):

1. Researcher's experiential knowledge: after over 20 years in a global business environment, we have got used to the mindsets of 'to think out of the box.' Despite many existing theories and research about leadership behaviour, we endeavour to other ideas from outside this traditionally defined field, to incorporate different attitudes and thoughts reflecting what managers experience in their real working life.

2. Existing theory and research: table 1 presents a brief previous research on different leadership behaviours.

3. Our pilot and exploratory research: we attempt to integrate different approaches survey, in-depth interview and observation. We utilize the triangulation approach in order to get greater breadth of perspectives and a deeper understanding of the leadership 
TABLE 1 Previous Research on Leadership Behaviours

\begin{tabular}{|c|c|c|}
\hline Category & Authors & Focus on \\
\hline \multirow{11}{*}{$\begin{array}{l}\text { Relations- } \\
\text { oriented } \\
\text { leadership } \\
\text { behaviours }\end{array}$} & Hemphill (1950) & $\begin{array}{l}\text { Consideration regarding wellbe- } \\
\text { ing and contributions of followers }\end{array}$ \\
\hline & Fleishman (1957) & Emphasizing employee needs \\
\hline & Blake and Mouton (1964) & Concern for people \\
\hline & Mann (1965) & Human relation orientation \\
\hline & Bowers and Seashore (1966) & $\begin{array}{l}\text { Interaction facilitative and sup- } \\
\text { portive }\end{array}$ \\
\hline & Anderson (1974) & People centred \\
\hline & Ouchi (1981) & Participatory decision-making \\
\hline & Misumi and Peterson (1985) & $\begin{array}{l}\text { Building mutual trust and demo- } \\
\text { cratic }\end{array}$ \\
\hline & Bass and Avolio $(1995 ; 1997)$ & $\begin{array}{l}\text { Idealized influence, individual- } \\
\text { ized consideration, intellectual } \\
\text { stimulation, and inspirational } \\
\text { motivation. }\end{array}$ \\
\hline & Griffin and Ebert (2010) & $\begin{array}{l}\text { Prioritize the welfare of everyone } \\
\text { in a team }\end{array}$ \\
\hline & Conger (2011) & $\begin{array}{l}\text { Encouraging the interaction } \\
\text { within teams }\end{array}$ \\
\hline \multirow{10}{*}{$\begin{array}{l}\text { Task- } \\
\text { oriented } \\
\text { leadership } \\
\text { behaviours }\end{array}$} & Hemphill (1950) & Initiating structure \\
\hline & Katz, Maccoby, and Morse (1950) & Focused on production \\
\hline & Fleishman (1951) & Defining group activities \\
\hline & Fleishman (1957) & Production emphasizing \\
\hline & Cartwright and Zander (1960) & Goal achieving \\
\hline & Blake and Mouton (1964) & Concerned with production \\
\hline & Bowers and Seashore (1966) & Goal emphasizing \\
\hline & Reddin (1977) and Zaleznik (1977) & Autocratic and management \\
\hline & Indvik (1986) & Achievement oriented \\
\hline & $\begin{array}{l}\text { Bass and Avolio (1995; 1997) } \\
\text { Bass }(2000) \\
\text { Bass and Bass }(2008) \\
\text { Conger }(2011) \\
\end{array}$ & $\begin{array}{l}\text { Contingent reward, } \\
\text { management-by-exception } \\
\text { (active), and management-by- } \\
\text { exception (passive) }\end{array}$ \\
\hline \multicolumn{2}{|c|}{$\begin{array}{l}\text { Non relations-oriented } \\
\text { and non-task-oriented }\end{array}$} & $\begin{array}{l}\text { Laissez-faire, avoid making deci- } \\
\text { sions }\end{array}$ \\
\hline
\end{tabular}

behaviour phenomenon, not leadership in general (Mingers 2001; Venkatesh, Brown, and Bala 2013). Through multiple investigation lines, we are more confident in our research data and enhance the creative potential of the study; consequently, we are able to provide a clearer understanding of the problem and easily to reveal unique findings (Thurmond 2001). 
TABLE 1 Continued from the previous page

\begin{tabular}{lll}
\hline Category & Authors & Focus on \\
\hline 13 relevant & De Jong and Den & Innovative role-modelling, support for innova- \\
leadership & Hartog (2007) & tion, intellectual stimulation, stimulating knowl- \\
behaviours & & edge diffusion, providing vision, providing re- \\
findings & & sources, organizing feedback, consulting, del- \\
& & egating, monitoring, recognition, rewards and \\
& task assignment. \\
\hline
\end{tabular}

4. Our thought experiments: the purpose of our thought experiments is to describe reality, the present business environment. The most essential objectives that could define business success should be people and goal. However, how could the people reach the goal, in which way? The answer is we have to act and achieve it in a good procedure or process.

While management and leadership are distinct concepts or views, in this study, leadership and management are roles that are not mutually exclusive because our informants fulfilled these roles. We use 'managers' and 'leaders' interchangeable in referring to the informants (see De Jong and Den Hartog, 2007).

\section{Research Methodology}

This paper adopts the mixed methods approach, which combines qualitative and quantitative methods, involving the use a questionnaire, followed by in-depth interviews, in order to examine the behaviours of 20 managers from three management levels (directors, general managers and line managers) within a global company. The purpose in applying this method is to integrate all the collected information into a cohesive whole, as well as increase confidence in the research data, reveal unique findings, integrate theories and provide a clearer understanding of the problem (Jackson and Parry 2011; Venkatesh, Brown, and Bala 2013). Figure 2 describes our research design.

The weak and semi-strong market test (Jensen 1978; Forss 2013) was conducted in the form of a short interview with a director, a general manager and a line manager to confirm the inter-correlations of the findings.

\section{QUESTIONNAIRE}

The questionnaire used in this study was designed as a web survey. The survey introduction briefed the respondent about the purpose of the study and provided a confidentiality statement. The invitation 


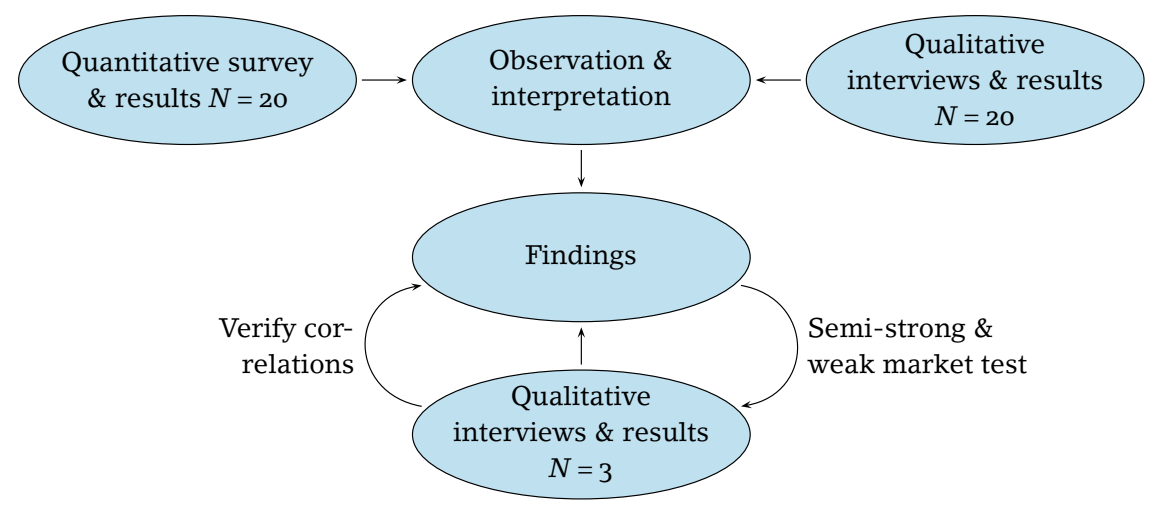

FIGURE 2 Research Design

was sent to 28 leaders across different organisational levels in 2016, 20 of whom agreed to participate in the research. At that point, a time and date were established for interviews, while leaders were asked to fill in the survey at their earliest convenience. A personal code was also given to each leader in order to complete the web survey so that his/her answers could be correctly attached to his/her interview responses for the purposes of data analysis.

The goal of the survey was to identify the participants' leadership profile and investigate how leaders utilized their organization's existing resources (such as their people, know-how, processes and information technology systems), as well as how they applied their ability to lead people in order to achieve a long-term or overall aim. The survey consisted of two main parts: the first part, which was fully consumed in this study, included 11 questions related to the participants' background; the second part contained 14 questions covering 14 leadership behaviours, which were incorporated into the transformational leadership sand cone model (Ha-Vikström and Takala $2016 \mathrm{a} ; 2016 \mathrm{~b} ; 2016 \mathrm{c}$ ), of which only 50\% were used in this study because they focused on important insights of behaviours and attitudes among leaders. Furthermore, due to the space limitations in the article, we decided not to present the remaining survey results, as they were related to the effectiveness of transformational leadership.

In order to meet the aim of the research and maximize the likelihood of honest responses from the participants, we emphasized in the survey that there were no right or wrong answers, as well as stressed that all answers were completely anonymous. This should have helped to reduce the anxiety of the participants or ensured that they were 'less likely to edit their responses to be more consistent 
with how they think the researcher wants them to respond' (Podsakoff et al. 2003).

\section{IN-DEPTH INTERVIEWS}

We conducted interviews throughout October and November 2016. The purpose of the interviews was to capture the attitudes, behaviours and perspectives in the context of being a manager in a global company. Skype video calling was used to make it possible for the interviewees to participate. Before recording the interview, we clearly explained to the participants about the aims and importance of the study, as well as assured them about the confidentiality. A semi-structured interview technique was used with four key open-ended questions and follow-up questions (Seidman 2013; Padgett 2016). Overall, 20 interviews were conducted, with each interview typically lasting less than an hour. The interviews were audio recorded for transcription and coding purposes. Furthermore, in the verification phase, after the results were generated, we also conducted a short interview, which is known as a weak and semi-strong market test with three leaders (a director, a general manager and a line manager) to confirm our final results.

\section{OBSERVATION}

We could utilize the 'complete participant' or 'participant observation' type in this study, which means the researcher intervenes in the environment (Gold 1958) due to that the researcher has been working in the studied company over the past 20 years. Based on that, the participants have been well known to the researcher in different contexts for a quite long time. This existence of a long-term relationship helped the researcher disclose the leaders' deeper thoughts and feelings better than otherwise would have been possible (Maclean, Harvey, and Chia 2012). As this study focused on the leaders' behaviour and attitude, that perception could be effortlessly observed via social contact and business relationship. In order to make the observations more reliable, we quantified the observation data, and in unclear circumstances the researcher contacted the informants for confirmation. From such a perspective, the observations in this study play an extra role to strengthen the facts based on the data collected from the questionnaire and the interviews.

DATA COLLECTION

The details of the data collection obtained from the questionnaire are presented in table 2 . 
TABLE 2 Data Collection Obtained from the Questionnaire

\begin{tabular}{|c|c|c|c|}
\hline \multirow[t]{3}{*}{ Position } & Directors & 35 & $(7 / 20)$ \\
\hline & General managers & 45 & $(9 / 20)$ \\
\hline & Line managers & 20 & $(4 / 20)$ \\
\hline \multirow[t]{2}{*}{ Gender } & Male & 65 & $(12 / 20)$ \\
\hline & Female & 35 & $(7 / 20)$ \\
\hline \multirow[t]{2}{*}{ Leaders' nationality region } & Northern Europe & 90 & $(18 / 20)$ \\
\hline & Asia & 10 & $(2 / 20)$ \\
\hline \multirow[t]{3}{*}{ Age } & $35-44$ years & 25 & $(5 / 20)$ \\
\hline & $45^{-54}$ years & 50 & $(10 / 20)$ \\
\hline & $>54$ years & 25 & $(5 / 20)$ \\
\hline \multirow[t]{2}{*}{ Working experience } & 6-19 years & 50 & $(10 / 20)$ \\
\hline & $>20$ years & 50 & $(10 / 20)$ \\
\hline \multirow[t]{3}{*}{ Leadership experience } & 1-5 years & 10 & $(2 / 20)$ \\
\hline & 6-10 years & 25 & $(5 / 20)$ \\
\hline & $>10$ years & 65 & $(13 / 20)$ \\
\hline \multirow[t]{2}{*}{ Total number of subordinates } & Less than 10 & 50 & $(10 / 20)$ \\
\hline & More than 10 & 50 & $(10 / 20)$ \\
\hline \multirow[t]{4}{*}{ Education } & Doctoral degree & 5 & $(1 / 20)$ \\
\hline & Master's degree & 50 & $(10 / 20)$ \\
\hline & Bachelor's degree & 35 & $(7 / 20)$ \\
\hline & Below вsc & 10 & $(2 / 20)$ \\
\hline
\end{tabular}

\section{DATA ANALYSIS}

The data analysis was conducted in five steps. First, the interviews were transcribed verbatim into a text file, after which we manually separated the original raw data into Excel to enable easy sorting, filtering and grouping of the data for later comparison. Second, we performed content analysis to analyse the text in the transcripts and identify the core meaning behind each answer. Third, based on these core meanings, we identified the categories or patterns by using a technique called 'open coding' (Strauss and Corbin 1998, 223) or 'analytical coding' (Corbin and Strauss 2007; Merriam and Tisdell 2015). In this stage, we worked back and forth between these codes (Saldaña 2015) in the whole data set, searching for meaningful labels and themes. Next, we used the 'quantitizing' technique of Miles and Huberman (1994) to convert the qualitative data or verbal results into numerical responses. Fourth, we calculated the survey results for each respondent and then compared these results with the data obtained from the interviews (the third step above) by applying the 'member checking' strategy, which sends the results of the analysis 
back to the participants. In this sense, the survey data became more meaningful when interpreted in the light of essential qualitative information; at the same time, we were able to identify ambiguous or uncertain information. Fifth, with the use of a constant comparative method (Lincoln and Guba 1985; Lincoln, Lynham, and Guba 2011), we compared all data with each other, searching for convergences and eliminating discrepancies. This technique provided a rather rich and comprehensive picture of leaders' behaviour, such that we were able to discover contextual patterns and uncover different dimensions of the research problem.

\section{VALIDITY AND RELIABILITY}

In order to ensure the internal and external reliability of the measurements, we utilized different techniques for controlling common method biases. Firstly, in terms of internal validity, we utilized data triangulation, both quantitatively and qualitatively, in order to increase the credibility and validity of the results. Furthermore, we also conduct a control test for each equation.

Secondly, for external validity, we followed Jensen (1978) and Forss (2013) in choosing a weak and semi-strong market test to check low and high data correlation coefficients acquired from our intercorrelations analysis. This was carried out by interviewing three managers (a director, a general manager and a line manager), in which we showed them the final results in order to receive their feedback and confirmation. A tabulated presentation of the data analysis and inter-correlations between 14 factors can be found in the discussion section. Finally, we consulted the literature related to different types of leadership behaviour in order to verify and validate the findings. In all, this indicates that the measurement method used has internal and external reliability.

\section{Findings}

The data analysis reveals seven specific pairwise categories reflecting leaders' behaviour and their actual deep meanings in real-life context, as follows.

\section{PAIR 1: FACTS VERSUS PHILOSOPHY}

Between being a doer (facts) and being a thinker (philosophy), Hill (2003) highlights that, prior to managerial promotion, most people work as 'doers' or contributors; their primary responsibility is to perform tasks. Meanwhile, the 'thinker' prefers to seek a wider context, 
imagines different possibilities of how things should be done, considers why or how everything connects and so forth. Fullan (2006) defines another type of leaders' behaviour, that is, 'system thinkers or theoreticians.' In fact, the essence perception of this pairwise distinction 'facts versus philosophy' is essentially about a theory of attitude, which acts as a guiding principle for leadership behaviour. The distinction between these two behaviours can be interpreted and evaluated throughout our interviews and observations, especially in the first interview question when the leaders were asked to narrate their own professional career story. Philosophical leaders tend to describe their career story in a figurative or poetic way, for example, a respondent could take several minutes to answer a short question:

In an earlier part of my career in 1992, I learned from other leaders and copied what they did a little bit. A leader is someone who really believes in you and trusts you [the participant explained with an example]. When the guy is actually trying his best, why interfere. [Male general manager - philosophy]

Meanwhile, factual leaders tend to express themselves in a more specific, literal way, for example:

I started 22 years ago as project engineer. In 1999, I moved over to become a development manager, but I left the company in 2002. Two years later, in 2004, I returned. And since the beginning of 2009, I have been a general manager ... [Male general manager - facts]

\section{PAIR 2: RESULTS VERSUS COACH-ORIENTED}

In order to be successful in organisational settings and responding to needs, leaders will either use behaviours and orientations, in order to lead their followers towards delivering the highest level of performance (results-oriented), or collaborate and foster an individualized relationship with their followers in order to work together on reaching an agreed-upon destination (coach-oriented).

According to MacKenzie, Podsakoff, and Rich (2001) and Yukl (2002), coaching and mentoring tend to be viewed as more useful for leading employees because they are tailored to individual needs, especially among those who are expected to work in unfamiliar or new situations, as well as assume new responsibilities.

Results-based orientations, however, are regarded as involving more stable personality traits (Payne, Youngcourt, and Beaubien 2007), in which people tend to judge successful performance (Roberts, Treasure, and Conroy 2007). 
When we asked about leadership identity, leaders described their own identity when leading people. The purpose of this question was to determine whether the focus of leaders was on outcomes/goals or on coaching/mentoring; $65 \%$ of managers admitted that they implement a coaching style:

My role is as a coaching type of leader. I listen and try to allow the person to find out the answers. If needed, I give advice, brainstorm together and try to find solutions. [Female general manager - coach]

Meanwhile, 35\% of managers acknowledged that they were more results- or goal-focused:

Somebody might say that I was a born leader, but it's more about a willingness to get things done. If I think that things are not proceeding, I really take the lead, I tend to get things done and get them running. [Male general manager - results]

PAIR 3: PROCEDURES VERSUS HUMAN RELATIONS

For evaluation purposes, in this paragraph, we use the term process for procedures and people for human relations. Process-focused leadership is a behavioural approach in which the leader focuses on the process that needs to be performed in order to meet certain goals, i.e., an adaptation of the task-focused leadership definition by Forsyth (2010). People-focused leadership is a behavioural approach in which the leader focuses on the satisfaction, motivation and general well-being of team members. The interviews and survey responses demonstrated that $80 \%$ of managers were more peoplefocused:

People will do their best when they know I care ... You really communicate with people, you inform them, follow-up, but you also really have to show that you care for them. [Male line manager - people/human relations]

I want to see the big picture, supporting people, developing trust, being empathetic, listening to people, understanding how team members feel. [Male director - people/human relations]

Listen to your people, your mind and heart, and always be honest ... I usually say that you have to always keep your ears and eyes open, observing, talking with your people. [Male director people/human relations]

Meanwhile, $20 \%$ of managers admitted that they were more process-focused: 
I'm quite structured and would like my subordinates to be structured, by being somewhat punctual. [Male line manager - process/procedures]

I do not consider myself as a micro manager, but it's easier to lead an operational team. [Female general manager - process/procedures]

\section{PAIR 4: INTROVERT VERSUS EXTROVERT}

Allbeck and Badler (2008) explain that personality is a pattern of behaviour, which includes introversion and extroversion. Furthermore, in Western European or American culture, it is well documented, according to Zaccardi, Howard, and Schnusenberg (2012) that the perception of a successful leader is one with outgoing characteristics that is a charismatic extrovert. In other cultures, it is also well known that having an extrovert in a leadership role means there is a more evident connection to people, active engagement and enthusiasm than is observed from a reserved introvert.

However, a recent study conducted by Stephens-Craig, Kuofie, and Dool (2015) revealed that the majority of participants believed both introverts and extroverts could be successful leaders, while just a few participants were minded that only extroverts could be effective leaders. This finding is based on qualitative research involving 31 mid- to high-level leaders in a variety of occupations. In fact, regardless of the preference for introversion or extroversion, each individual is capable of learning and compensating for one's own weaknesses in order to adapt and operate in the corporate world, a world that may be designed for extroverts (Stephens-Craig, Kuofie, and Dool 2015). The interviews demonstrated that $25 \%$ of respondents were introverts:

My personality is introverted. I use up my energy if there is a lot of controversy and hassle. [Female director - introvert]

I prefer to work independently in my own office, a workplace that allows you to work innovatively. [Male line manager - introvert]

Meanwhile, $75 \%$ of respondents admitted that they were more $e x-$ troverted:

I'm very extroverted. I would never be able to work on a longterm basis by myself, it would kill me. [Male director - extrovert] I'm not afraid to listen and talk to different people ... I want 
to communicate with people, that's a sustainable approach. [Female general manager - extrovert]

\section{PAIR 5: THE PAST VERSUS THE FUTURE}

Future orientation, which is derived from Kluckhohn and Strodtbeck (1961), is the degree to which individuals in organisations engage in future behaviours, such as planning and investing in the future. Shenhar (1993) emphasizes that future-oriented behaviour reduces uncertainty. Furthermore, according to Ulrich, Zenger, and Smallwood (2013), the future is more important than the past because the working environment changes so quickly. Skip Prichard (2016), the CEO of Leadership Insight, argues that: 'It's always easier to stay where we are comfortable. But don't become an expert on the problem; become known as someone who drives to a better future. That's the essence of leadership.' That said, $70 \%$ of respondents indicated that they were more inclined towards to the future, as indicated by the following examples:

$I^{\prime} m$ interested in the future; I'm interested in looking at different ways of doing things, interested in figuring out what happens if we do something this way or another way. [Male general manager - future]

Meanwhile, approximately $30 \%$ of respondents tended to think about the past:

You should ask younger leaders to share [what they know] because now I have just $(\mathrm{x})$ years and $(\mathrm{x})$ months until retirement. With the situation that the company has today, I wouldn't want to stay more than a day longer. [Male general manager - past]

PAIR 6: LAISSEZ-FAIRE VERSUS PROACTIVE

Generally speaking, the laissez-faire attitude (letting things take their own course, without interfering) usually leads to lower productivity compared to a proactive attitude. Wooden and Jamison (2009) insist that 'successful leadership is not about being tough or soft, sensitive or assertive, but about a set of attributes; first and foremost is character ... get ready to respond quickly and correctly; intensity makes you stronger.'

Wooden and Jamison (2009) emphasize that a leader must have the initiative and courage to make decisions, as well a willingness to risk failure. Meanwhile, laissez-faire leadership should not be confused with empowering management; nor should it be confused with 
democratic leadership behaviour (Frischer 1993). However, the narrative data below are more about the attitudes displayed in the context of leaders' career development behaviour than any leadership style. Surprisingly, the interviews revealed that $20 \%$ of respondents tended to have adopt a laissez-faire attitude:

I'm the kind of person who needs to get support from a superior. My boss encouraged me to apply for a position that I wouldn't have necessarily considered myself. [Female general manager laissez-faire]

I've been pushed by managers, I've been lucky. My manager has been pushing me and got me moving forward, which is typical of my own professional career. Recently, changes and my manager forced me to take on a new role. [Female general manager - laissez-faire]

On the contrary, approximately $80 \%$ of managers claimed they were more proactive.

I am always proactive, motivating people and paying attention to each individual. [Male general manager - proactive]

I've done a lot of work on myself, investigated myself, my strengths and weaknesses, in order to develop myself all the time. [Female director - proactive]

I am always prepared and have a rough idea every week of what I need to do, how to better arrange my time and energy. [Male line manager - proactive]

\section{PAIR 7: UNPLANNED CAREER VERSUS PLANNED CAREER}

According to Wooden and Jamison (2009), any activity to produce real results must be organized and executed meticulously. In fact, anything that is achieved without effort is seldom worthwhile or long lasting. Furthermore, one essential element of leadership development is career planning. Surprisingly, $25 \%$ of respondents confessed that they had not planned for their career:

I have never had a plan to become anything, nor ever actively thought about my career. For me, it's all about learning, not about the career. [Male director - unplanned career]

I am not a career person. My career moves are more dependent on the moves in the organization. [Female general manager unplanned career] 
TABLE 3 A Sample of Verbal Results

\begin{tabular}{lrrrrr}
\hline Factors & \multicolumn{5}{c}{ Participant } \\
\cline { 2 - 6 } & Moderately & Moderately & Slightly & Slightly & Moderately \\
\cline { 2 - 6 } Facts & Moderately & Moderately & Very & Very & Moderately \\
Philosophy & Slightly & Slightly & Not at all & Moderately & Slightly \\
Results & Very & Very & Extremely & Moderately & Very \\
Coach & Slightly & Slightly & Not at all & Moderately & Slightly \\
Procedures & Very & Very & Extremely & Moderately & Very \\
Human relations & Slightly & Not at all & Slightly & Moderately & Slightly \\
Introvert & Very & Extremely & Very & Moderately & Very \\
Extrovert & Moderately & Moderately & Slightly & Extremely & Slightly \\
Past & Moderately & Moderately & Very & Not at all & Very \\
Future & Moderately & Moderately & Not at all & Extremely & Not at all \\
Laissez-faire & Moderately & Moderately & Extremely & Not at all & Extremely \\
Proactive & Extremely & Moderately & Not at all & Very & Not at all \\
Unplanned career & Not at all & Moderately & Extremely & Slightly & Extremely \\
Planned career & Extremer
\end{tabular}

Meanwhile, $75 \%$ of respondents admitted that they had intentionally put more focus on their leadership career.

I was prepared and ready to get a career, but started with an unclear situation. So, I created my own position and path, which has been leading me throughout my years in the company. Everything is possible and I can see openings. [Female general manager - planned career]

I have always had a personal career strategy, including in other perspectives, not just my working life. When I have a clear target, it is easier to aim at the ultimate goal. [Male general manager - planned career]

\section{MEASUREMENT}

We quantified each participant's behaviour by using a scale with five ratings: not at all, slightly, moderately, very and extremely. Table 3 present sample results for five participants (the entire results for all participants can be found in table 8).

Table 4 shows the same results, although the word rating was replaced with a quantitative rating: not at all $=0$, slightly $=0.25$, moderately $=0.5$, very $=0.75$ and extremely $=1$.

According to Brown (2003), personality is an outline of behaviour, while attitude is both a decision-oriented and learned behaviour. When we refer to a person's attitudes, we are trying to explain his 
TABLE 4 A Numeric Sample of Results

\begin{tabular}{lrrrrr}
\hline Factors & \multicolumn{3}{c}{ Participant } \\
\cline { 2 - 6 } & 1 & 2 & 3 & 4 & 5 \\
\hline Facts & 0.50 & 0.50 & 0.25 & 0.25 & 0.50 \\
Philosophy & 0.50 & 0.50 & 0.75 & 0.75 & 0.50 \\
Results & 0.25 & 0.25 & 0.00 & 0.50 & 0.25 \\
Coach & 0.75 & 0.75 & 1.00 & 0.50 & 0.75 \\
Procedures & 0.25 & 0.25 & 0.00 & 0.50 & 0.25 \\
Human relations & 0.75 & 0.75 & 1.00 & 0.50 & 0.75 \\
Introvert & 0.25 & 0.00 & 0.25 & 0.50 & 0.25 \\
Extrovert & 0.75 & 1.00 & 0.75 & 0.50 & 0.75 \\
Past & 0.50 & 0.50 & 0.25 & 1.00 & 0.25 \\
Future & 0.50 & 0.50 & 0.75 & 0.00 & 0.75 \\
Laissez-faire & 0.50 & 0.50 & 0.00 & 1.00 & 0.00 \\
Proactive & 0.50 & 0.50 & 1.00 & 0.00 & 1.00 \\
Unplanned career & 1.00 & 0.50 & 0.00 & 0.75 & 0.00 \\
Planned career & 0.00 & 0.50 & 1.00 & 0.25 & 1.00 \\
\hline
\end{tabular}

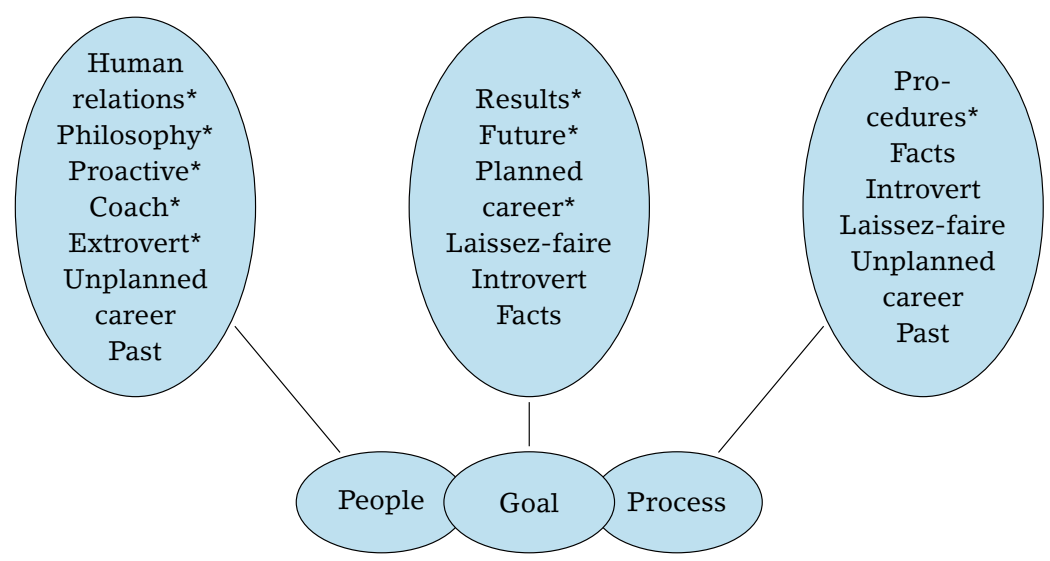

FIGURE 3 The Pattern of Leaders' Focus Areas

or her behaviour, which in turn helps us to define how we behave towards a situation or object. With this aspect in mind, and by individually and collectively examining the data set, we found that leaders' behaviours could be categorized into different attributes. Consequently, a pattern of people-, process and goal-focused behaviours was discovered. Figure 3 demonstrates the pattern of leaders' focus areas.

Large oval on the left contains five leading attributes: Human re- 
lations* (Hu), Philosophy* (Ph), Proactive* (Pro), Coach* (Co), and Extrovert* $^{*}$ Ex). In addition, it contains two sub- attributes or nonleading attributes: Unplanned career (Un_ca) and Past (Pa).

Large oval on the right contains one leading attribute: Procedure* (Proc). In addition, it contains five sub- attributes: Facts (Fa), Introvert (In), Past (Pa), Unplanned career (Un_ca), and Laissez-faire $(\mathrm{LF})$.

Large oval in the middle contains three leading attributes: Results* (R), Future* $(\mathrm{Fu})$, Planned career*, $\left(\mathrm{Pl} \_\mathrm{ca}\right)$ and three sub-attributes: Introvert (In), Facts (Fa), and Laissez-faire (LF).

All leading attributes are categorized into one of the focus areas (e.g. human relations belongs to People, results to Goal etc.). In addition, as the sub-attributes do not naturally belong to one of the two remaining focus areas, we decided to split them evenly. With this split, the sum of all attribute pairs equals to 1 , which ensures the validity of the mathematical model. This split is visible in the mathematical formulas where the sub-attributes are always divided by 2 .

Equation 1 was used to calculate people-focused leadership behaviour index, in which $\mathrm{Ph}=$ philosophy, $\mathrm{Co}=$ coach, $\mathrm{Hu}=$ human relations, $\mathrm{Ex}=$ extrovert, $\mathrm{Pa}=$ past, $\mathrm{Pro}=$ proactive, and Un_ca $=$ unplanned career.

$$
\text { People }_{\text {focused }}=\frac{\mathrm{Ph}+\mathrm{Co}+\mathrm{Hu}+\mathrm{Ex}+\frac{\mathrm{Pa}}{2}+\operatorname{Pro}+\frac{\mathrm{Un}_{\_} \mathrm{ca}}{2}}{7} \times 100 .
$$

Equation 2 was used to calculate process-focused leadership behaviour, in which $\mathrm{Fa}=$ facts, $\mathrm{Proc}=$ procedures, $\mathrm{In}=$ introvert, $\mathrm{Pa}=$ past, $\mathrm{LF}=$ laissez-faire, and Un_ca $=$ unplanned career.

$$
\text { Process }_{\text {focused }}=\frac{\frac{\mathrm{Fa}}{2}+\operatorname{Proc}+\frac{\mathrm{In}}{2}+\frac{\mathrm{Pa}}{2}+\frac{\mathrm{LF}}{2}+\frac{\mathrm{Un} \_\mathrm{ca}}{2}}{7} \times 100 .
$$

Equation 3 was used to calculating goal-focused leadership behaviour, in which $\mathrm{Fa}=$ facts, $\mathrm{R}=$ results, $\mathrm{In}=$ introvert, $\mathrm{Fu}=$ future, $\mathrm{LF}=$ laissez-faire, and Pl_ca = planned career.

$$
\begin{aligned}
& \text { Goal }_{\text {focused }}=\frac{\frac{\mathrm{Fa}}{2}+\mathrm{R}+\frac{\mathrm{In}}{2}+\mathrm{Fu}+\frac{\mathrm{LF}}{2}+\mathrm{Pl}{ }_{-} \mathrm{ca}}{7} \times 100 . \\
& \text { People }_{\text {focused }}+\text { Process }_{\text {focused }}+\text { Goal }_{\text {focused }}=100 .
\end{aligned}
$$

Table 5 shows the results from the 20 participants.

Due to the high level of skewness between people-focused variables, we decided to use the median (the midpoint of a frequency distribution of observed values) to calculate the focus results for 
TABLE 5 Results from the 20 Participants

\begin{tabular}{lrrr}
\hline Particip. & People & Process & Goal \\
\hline 1 & 0.571 & 0.232 & 0.196 \\
2 & 0.571 & 0.179 & 0.250 \\
3 & 0.661 & 0.054 & 0.286 \\
4 & 0.464 & 0.339 & 0.196 \\
5 & 0.554 & 0.107 & 0.339 \\
6 & 0.696 & 0.036 & 0.268 \\
7 & 0.429 & 0.250 & 0.321 \\
8 & 0.464 & 0.179 & 0.357 \\
9 & 0.589 & 0.089 & 0.321 \\
10 & 0.393 & 0.214 & 0.393 \\
11 & 0.411 & 0.179 & 0.411 \\
12 & 0.375 & 0.196 & 0.429 \\
13 & 0.464 & 0.250 & 0.286 \\
14 & 0.411 & 0.250 & 0.339 \\
15 & 0.286 & 0.196 & 0.518 \\
16 & 0.429 & 0.196 & 0.375 \\
17 & 0.393 & 0.214 & 0.393 \\
18 & 0.732 & 0.125 & 0.143 \\
19 & 0.607 & 0.107 & 0.286 \\
20 & 0.554 & 0.107 & 0.339 \\
\hline
\end{tabular}

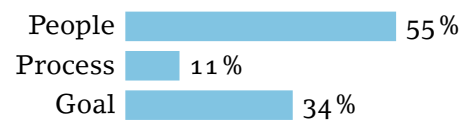

FIGURE 4 Key Focus Areas for Directors

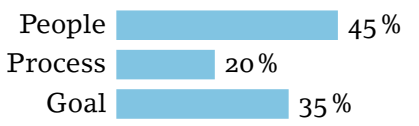

FIGURE 5 Key Focus Areas for General Managers

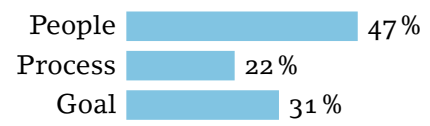

FIGURE 6 Key Focus Areas for Line Managers

\begin{tabular}{r|c|} 
People & \multicolumn{1}{c}{$47 \%$} \\
Process & $19 \%$ \\
Goal & \multicolumn{1}{c}{$34 \%$} \\
FIGURE 7 & $\begin{array}{l}\text { Key Focus Areas for all } \\
\text { Participants }\end{array}$
\end{tabular}

TABLE 6 Total Results

\begin{tabular}{lrrr}
\hline Position & People-focused & Process-focused & Goal-focused \\
\hline Directors & $55 \%$ & $12 \%$ & $33 \%$ \\
General managers & $50 \%$ & $17 \%$ & $33 \%$ \\
Line managers & $48 \%$ & $21 \%$ & $31 \%$ \\
\hline
\end{tabular}

each management level. Figure 4 presents the key focus areas for directors, figure 5 presents the key focus areas for general managers and figure 6 presents the key focus areas for Line Managers. Finally, figure 7 presents the total focus areas for all participants.

\section{Discussion}

This study presented an outline of behaviour (personality) and learned behaviour (attitude) as perceived and experienced by managers in a global company. We utilized a mixed methods approach to answer the research question: How is leadership behaviour manifested across organisational levels?

Table 6 presents the percentage of the total results for the three or- 
ganisational levels. From a big picture perspective, the results show that the largest focus area for all three management team levels is people (Dir $=55 \%, \mathrm{GM}=50 \%, \mathrm{LM}=48 \%)$. The second largest focus area is goal ( $\mathrm{Dir}=33 \%, \mathrm{GM}=33 \%, \mathrm{LM}=31 \%)$, while the last focus area is process ( $\mathrm{Dir}=12 \%, \mathrm{GM}=17 \%, \mathrm{LM}=21 \%$ ). The total results are displayed in table 6. Surprisingly, directors focus most of all on people $(55 \%)$ and least of all on process $(12 \%)$. As Harrington $(2011,122) \mathrm{em}-$ phasizes, 'the process is brought to life by people, our people make the process work, without them, we have nothing.' Furthermore, the people-focused results in this research are supported by the findings of Larsson and Vinberg (2010), who found that people-oriented leadership behaviour was by far the strongest in three-dimensional leadership behaviour theory (change, structure and people orientation).

The results also show that directors focus least on process compared with general and line managers (Dir $=12 \%, \mathrm{GM}=17 \%, \mathrm{LM}=$ $21 \%$ ), which could be regarded as both logical and understandable because directors probably focus more on the big picture compared to their subordinates. Furthermore, line managers inevitably focus more on process than general managers and directors, given that the former's subordinates typically perform operational tasks where processes are important.

Although goals or results are usually considered to be the final measure of success, the outcomes unexpectedly show an almost identical focus on goals across the three management levels (Dir = $33 \%, \mathrm{GM}=33 \%, \mathrm{LM}=31 \%$ ), even though many researchers argue that process should be focused on more than goals (Wooden and Jamison 2009). Furthermore, business processes can help organisations vastly improve their effectiveness and the quality of their products and services (Harrington 2011).

Let us now look at the context of 'weak or strong position power' among the directors from a medium-sized company who participated in this study, where a director is typically below three other chief positions, namely, chief information officer, chief financial officer/chief digital officer and chief executive officer. This 'position power' aspect may have some influence on the focus of directors.

Table 7 presents the inter-correlation matrix of 14 variables. In general, the correlations were rather high between several variables, including between the 'human relations' and 'procedures' variables (0.91), or between the 'proactive' and 'future' variables (0.78). Conversely, the coefficient correlation between the 'planned career' and 'introvert' variables was very low (0.01). However, this low correla- 
TABLE 7 Inter-Correlation Matrix for Study Variables

\begin{tabular}{|c|c|c|c|c|c|c|c|c|c|c|c|c|c|}
\hline & (1) & (2) & (3) & (4) & (5) & (6) & (7) & (8) & (9) & (10) & (11) & (12) & (13) \\
\hline (1) & 1 & & & & & & & & & & & & \\
\hline (2) & -1 & 1 & & & & & & & & & & & \\
\hline (3) & .534 & -.534 & 1 & & & & & & & & & & \\
\hline (4) & -.534 & .534 & -1 & 1 & & & & & & & & & \\
\hline (5) & .588 & -.588 & .913 & -.913 & 1 & & & & & & & & \\
\hline (6) & -.588 & .588 & -.913 & .913 & -1 & 1 & & & & & & & \\
\hline (7) & .212 & -.212 & .468 & -.468 & .307 & -.307 & 1 & & & & & & \\
\hline (8) & -.212 & .212 & -.468 & .468 & -.307 & .307 & -1 & 1 & & & & & \\
\hline (9) & -.043 & .043 & .126 & -.126 & .290 & -.290 & -.100 & .100 & 1 & & & & \\
\hline (10) & .043 & -.043 & -.126 & .126 & -.290 & .290 & .100 & -.100 & -1 & 1 & & & \\
\hline (11) & -.139 & .139 & .179 & -.179 & .289 & -.289 & .104 & -.104 & .777 & -.777 & 1 & & \\
\hline (12) & .139 & -.139 & -.179 & .179 & -.289 & .289 & -.104 & .104 & -.777 & .777 & -1 & 1 & \\
\hline (13) & -.248 & .248 & -.254 & .254 & -.182 & .182 & -.010 & .010 & .536 & -.536 & .660 & -.660 & 1 \\
\hline (14) & .248 & -.248 & .254 & -.254 & .182 & -.182 & .010 & -.010 & -.536 & .536 & -.660 & .660 & -1 \\
\hline
\end{tabular}

Notes Column/row headings are as follows: (1) facts, (2) philosophy, (3) results, (4) coach, (5) procedures, (6) human relations, (7) introvert, (8) extrovert, (9) past, (10) future, (11) laissez-faire, (12) proactive, (13) unplanned career, (14) planned career.

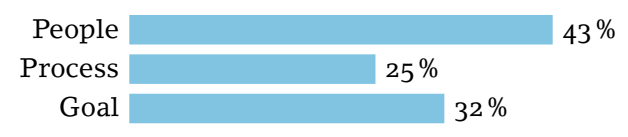

FIGURE 8 Optimal Key Focus Areas

tion is logical and understandable because these two variables are independent of each other.

To conclude, where a participant has seven pair factors of the same neutral weight (moderately $=0.5$ ), applying this value to the Equations 1, 2 and 3 produces the following results: people-focused $=43 \%$; process-focused $=25 \%$; goal-focused $=32 \%$. These percentages can be considered as the optimal values for people, process and goal modelling, if we exclude all potentially influencing factors on the results (such as gender, position power or the financial situation of the studied company). Figure 8 presents an optimal people, process and goal model.

\section{THEORETICAL IMPLICATIONS}

This study conveys several theoretical implications for leadership research. The first and major theoretical contribution is the proposed normative model. Our results reveal the existence of a pattern of leadership behaviour in three focus areas: people, process and goal. This pattern signifies the strategic choices made to ensure the organization's long-term success. 
People-, Process- and Goal-Focused Leadership Behaviour

TABLE 8 Total Verbal Results

\begin{tabular}{|c|c|c|c|c|c|c|c|}
\hline (1) & Facts & Philosophy & Results & Coach & Process & $\begin{array}{l}\text { Human } \\
\text { relations }\end{array}$ & Introvert \\
\hline 1 & Moderately & Moderately & Slightly & Very & Slightly & Very & Slightly \\
\hline 2 & Moderately & Moderately & Slightly & Very & Slightly & Very & Not at all \\
\hline 3 & Slightly & Very & Not at all & Extremely & Not at all & Extremely & Slightly \\
\hline 4 & Slightly & Very & Moderately & Moderately & Moderately & Moderately & Moderately \\
\hline 5 & Moderately & Moderately & Slightly & Very & Slightly & Very & Slightly \\
\hline 6 & Not at all & Extremely & Not at all & Extremely & Not at all & Extremely & Slightly \\
\hline 7 & Moderately & Moderately & Moderately & Moderately & Moderately & Moderately & Moderately \\
\hline 8 & Moderately & Moderately & Moderately & Moderately & Moderately & Moderately & Slightly \\
\hline 9 & Moderately & Moderately & Slightly & Very & Slightly & Very & Not at all \\
\hline 10 & Very & Slightly & Very & Slightly & Very & Slightly & Slightly \\
\hline 11 & Moderately & Moderately & Very & Slightly & Very & Slightly & Not at all \\
\hline 12 & Very & Slightly & Moderately & Moderately & Moderately & Moderately & Moderately \\
\hline 13 & Very & Slightly & Slightly & Very & Moderately & Moderately & Slightly \\
\hline 14 & Very & Slightly & Moderately & Moderately & Very & Slightly & Slightly \\
\hline 15 & Very & Slightly & Very & Slightly & Moderately & Moderately & Extremely \\
\hline 16 & Very & Slightly & Moderately & Moderately & Moderately & Moderately & Slightly \\
\hline 17 & Very & Slightly & Moderately & Moderately & Moderately & Moderately & Very \\
\hline 18 & Moderately & Moderately & Not at all & Extremely & Not at all & Extremely & Not at all \\
\hline 19 & Moderately & Moderately & Slightly & Very & Slightly & Very & Not at all \\
\hline 20 & Very & Slightly & Slightly & Very & Slightly & Very & Not at all \\
\hline (1) & Extrovert & Past & Future & $\begin{array}{l}\text { Laissez- } \\
\text { faire }\end{array}$ & Proactive & $\begin{array}{l}\text { Unplanned } \\
\text { career }\end{array}$ & $\begin{array}{l}\text { Planned } \\
\text { career }\end{array}$ \\
\hline 1 & Very & Moderately & Moderately & Moderately & Moderately & Extremely & Not at all \\
\hline 2 & Extremely & Moderately & Moderately & Moderately & Moderately & Moderately & Moderately \\
\hline 3 & Very & Slightly & Very & Not at all & Extremely & Not at all & Extremely \\
\hline 4 & Moderately & Extremely & Not at all & Extremely & Not at all & Extremely & Not at all \\
\hline 5 & Very & Slightly & Very & Not at all & Extremely & Not at all & Extremely \\
\hline 6 & Very & Not at all & Extremely & Not at all & Extremely & Slightly & Very \\
\hline 7 & Moderately & Moderately & Moderately & Moderately & Moderately & Moderately & Moderately \\
\hline 8 & Very & Slightly & Very & Slightly & Very & Slightly & Very \\
\hline 9 & Extremely & Slightly & Very & Not at all & Extremely & Not at all & Extremely \\
\hline 10 & Very & Moderately & Moderately & Not at all & Extremely & Not at all & Extremely \\
\hline 11 & Extremely & Slightly & Very & Slightly & Very & Not at all & Extremely \\
\hline 12 & Moderately & Slightly & Very & Slightly & Very & Not at all & Extremely \\
\hline 13 & Very & Moderately & Moderately & Moderately & Moderately & Moderately & Moderately \\
\hline 14 & Very & Moderately & Moderately & Slightly & Very & Slightly & Very \\
\hline 15 & Not at all & Not at all & Extremely & Not at all & Extremely & Not at all & Extremely \\
\hline 16 & Very & Slightly & Very & Slightly & Very & Slightly & Very \\
\hline 17 & Slightly & Slightly & Very & Not at all & Extremely & Slightly & Very \\
\hline 18 & Extremely & Slightly & Very & Not at all & Extremely & Extremely & Not at all \\
\hline 19 & Extremely & Moderately & Moderately & Not at all & Extremely & Not at all & Extremely \\
\hline 20 & Extremely & Slightly & Very & Not at all & Extremely & Not at all & Extremely \\
\hline
\end{tabular}

notes (1) Participant.

Secondly, our study addresses calls for research on the link between the paths of people-, process- and goal-focused leadership behaviour that no prior researchers have considered. Finally, our finding provides a new insight into how leadership behaviour manifests differently across organisational levels. 
The findings of this study contribute to managerial practices. Our results pinpoint the percentage of specific behaviours that leaders can follow to develop their leadership skills as well as to find the desired balance for their own organisational success. In addition, organisations can utilise the People, Process and Goal model for recruitment, selection or to find the right competent leaders to the right positions. Especially, the model can be used as a compass for leadership development programs to train leaders according to the vision and mission of the organisations. Finally, our findings provide a new instrument and methodology to measure the convergence of leadership behaviour, which will assist the organisation to achieve the greater success.

\section{LIMITATIONS AND OPPORTUNITIES FOR FURTHER RESEARCH}

The first limitation to consider is related to the features of the sample. We do not know whether these results would have been generalizable had the sample size been somewhat larger or more genderbalanced, or if the participants' nationalities had been those other than Northern European.

The second possible limitation is related to the time-dependent variables and conditions. It is unknown whether the results would have been the same had the data gathering process been conducted in another period, for example, when the financial situation of the company was significantly different. As Ha-Vikström and Takala (2016c), Jin, Seo, and Shapiro (2016), and Kazmi (2016) argue, when a company's financial status is low, this tends to negatively affect the atmosphere at work, as well as how leaders are perceived and behave. Therefore, further research involve a more diverse or balanced sample size, including within different organisational settings, such as the private sector versus the public sector, or for-profit organization versus non-profit organisations, in order to validate and verify the optimal values of the model.

Third, although our use of the triangulation of multiple sources, together with multidimensional levels of measurement and strong techniques, contribute to the confidence, credibility and trustworthiness of the results, an unavoidable shortcoming concerns the difficulty of replication. Hence, further studies should utilize the sevenfactor pairs in a survey, possibly using the analytic hierarchy process tool, in order to determine the focus of leaders' behaviour.

Finally, this study has only considered how leadership behaviour 
is manifested across three management team levels, while excluding the measurement of the respective company's performance. Therefore, further research to explore the relationship between the people, process and goal model and organisational performance is recommended.

\section{Conclusion}

This research has interrogated the leadership behaviours, as perceived and experienced by managers in a global company, through a triangulation method that no one had previously connected. The results reveal a pattern of leaders' behaviour in three key focus areas for success: people, process and goal. This paper not only contributes to our understanding of how leadership behaviour manifests differently across organisational levels, but also provides an instrument and methodology for measuring the convergence of leadership behaviours. The people, process and goal model can be used to directly support leaders in leading and improving their leadership skills, as well as to focusing their development efforts on their own organisational success. In addition, the model can also be used as a compass for organisations when considering leadership training programs or for recruitment, selection or promotion purposes. Finally, this empirical research study on leadership behaviour has identified productive opportunities for further research in order to develop a more effective leadership behaviour model that is applicable to different types of organisations.

\section{Acknowledgements}

I wish to thank Josu Takala, Tommi Lehtonen, and Marja Naaranoja who provide insight and expertise that greatly assisted this research. I also wish to thank Stiina Vistbacka and Vladimir Vbochko for their assistance. Finally, I am immensely grateful to every participant in the studied company, who provided interviews and survey responses for this study.

\section{Appendix 1: Interview Questions}

1. Please tell about your professional career story and significant career events. The purpose of this question is that the interviewees in a free manner describe the significant or important career events that they have had during their leadership career. A kind of success in their life-history narratives.

2. What has supported vs. what has prevented your development as a leader? This question seeks to explore the interviewees existing significant career events, based on those events, what has supported 
them to develop their leadership career versus what has hindered their leadership development.

3. Please describe your leadership identity or how you grow with your role as a leader. The purpose of this question is to investigate the interviewees' leadership identity, how do they further leverage their leadership brand, and how do they fill in gaps for even greater leadership.

4. What gives you energy for leadership activities vs. what takes energy away from you? The aim of this question is that the interviewees describe the positive versus negative thoughts on leadership activities that support or hinder their leadership career.

\section{Appendix 2: A Sample Excerpt from the Observations' Diary}

- Participant 9: a talkative and outgoing skillful leader, who enjoys being the center of attention.

- Participant 3: a warm empathetic and harmonic leader, who used to please other people and tends to pay attention of his actions in relation to others.

- Participant 15: a facts and details leader who likes to describe things in a specific way and focuses on how things are, prefers ideas that have practical application.

- Participant 7: a punctual leader who prefers step-by-step instructions, likes to make plans and deadline is very important.

- Participant 18: a very spontaneous leader who enjoys new situation, loves changing and quite flexibility with rules and deadlines.

- Participant 6: a calm leader who prefer to discuss possibilities of how things could be done in different way and likes to notice the big picture.

- Participant 4: a taciturn reserved leader who rather observe than stay in the center of attention.

- Participant 15: a fairness leader who likes fast actions and can make decision in an impersonal way.

\section{References}

Allbeck, J. M., and N. I. Badler. 2008. 'Creating Crowd Variation with the Ocean Personality Model.' Paper presented at the AAmas 2008 conference, Estoril, 12-6 May.

Anderson, D. E. 1974. 'Leadership Effectiveness in Education as Related to Congruence between Human Behavior Types and Leadership Styles.' PhD dissertation, Western Michigan University, Kalamazoo.

Antonakis, J., and R. J. House. 2014. 'Instrumental Leadership: Measurement and Extension of Transformational-Transactional Leadership Theory.' The Leadership Quarterly 25:746-71. 
Anzalone, C. 2012. 'Differences between Task-Oriented Leaders \& Relational-Oriented Leaders.' http://smallbusiness.chron.com/ differences-between-taskoriented-leaders-relationaloriented -leaders-35998.html

Bass, B., and B. Avolio. 1995. MLQ Multifactor Leadership Questionnaire. Redwood City, cA: Mind Garden.

- 1997. Full Range Leadership Development: Manual for the Multifactor Leadership Questionnaire. Redwood City, cA: Mind Garden.

Bass, B. 1967. 'Some Effects on a Group of Whether and When the Head Reveals His Opinion.' Organizational Behavior and Human Performance 2:375-82.

Bass, B. M., 2000. 'The Future of Leadership in Learning Organizations.' Journal of Leadership Studies 7 (3): 18-40.

Bass, B. M., and R. Bass. 2008. The Bass Handbook of Leadership: Theory, Research, and Managerial Applications. New York: Free Press.

Bass, B. M., B. J. Avolio, D. I. Jung, and Y. Berson. 2003. 'Predicting Unit Performance by Assessing Transformational and Transactional Leadership.' Journal of Applied Psychology 88:207-18.

Bass, B. M. 1990. Bass \& Stogdill's Handbook of Leadership: Theory, Research, and Managerial Applications. 3rd ed. New York, NY: Free Press.

Blake, R. R., and J. S Mouton. 1964. The Managerial Grid. Houston, Tx: Gulf.

Bowers, D. G., and S. E. Seashore. 1966. 'Predicting Organizational Effectiveness with a Four Factor Theory of Leadership.' Administrative Science Quarterly 11:238-63.

Brown, B. B. 2003. 'Employees' Organizational Commitment and Their Perception of Supervisors' Relations-Oriented and Task-Oriented Leadership Behaviors.' PhD Dissertation, Virginia Polytechnic Institute and State University, Blacksburg, vA.

Cartwright, D. E., and A.E. Zander. 1960. Group Dynamics. Evanston, IL: Row, Peterson \& Co.

Conger, J. A. 2011. 'Charismatic Leadership.' In The Sage Handbook of Leadership, edited by by A. Bryman, D. L. Collinson, K. Grint, B. Jackson, and M. Uhl-Bien, 86-102. Thousand Oaks, cA: Sage.

Corbin, J., and A. Strauss. 2007. Basics of Qualitative Research. 3rd ed. Thousand Oaks, cA: Sage.

De Jong, J. P., and D. N. Den Hartog. 2007. 'How Leaders Influence Employees' Innovative Behaviour.' European Journal of Innovation Management 10 (1): 41-64.

Fiedler, F. E., and R. J. House. 1988. 'Leadership Theory and Research: A Report of Progress.' In International Review of Industrial and Organizational Psychology, edited by C. L. Cooper and I. Robertson, 73-92. New York: Wiley. 
Fleishman, E. A. 1951. 'The Relationship between "Leadership Climate” and Supervisory Behavior.' PhD dissertation, Ohio State University, Columbus, он.

Fleishman, E. A. 1957. 'A Leader Behavior Description for Industry.' In Leader Behavior: Its Description and Measurement, edited by R. Stogdill and A. Coons, 10-119. Columbus, он: Ohio State University.

Fleishman, E. A. 1953a. 'The Description of Supervisory Behavior.' Journal of Applied Psychology 37 (1): 1-6.

Fleishman, E. A. 1953b. 'The Measurement of Leadership Attitudes in Industry.' Journal of Applied Psychology 37 (3): 153-8.

Forss, T. 2013. 'Improving Operational Performance within Social Housing.' PhD dissertation, University of Vaasa, Vaasa.

Forsyth, D. R. 2010. Group Dynamics. 5th ed. Belmont, cA: Wadsworth Cengage Learning.

Frischer, J. 1993. 'Empowering Management in New Product Development Units.' Journal of Product Innovation Management 10 (5): 393401.

Fullan, M. 2006. 'The Future of Educational Change: System Thinkers in Action.' Journal of educational change 7 (3): 113-22.

Gold, R. L. 1958. 'Roles in Sociological Field Observations.' Social Forces 36 (3): $217-23$.

Griffin, R. J., and R. W. Ebert. 2010. Business Essentials. 8th ed. Upper Saddle River, NJ: Prentice Hall.

Halpin, A. W. 1954. 'The Leadership Behavior and Combat Performance of Airplane Commanders.' Journal of Abnormal and Social Psychology 49 (1): 19-22.

Harrington, H. J. 1991. 'Improving Business Processes.' The тqм Magazine 3 (1): 39-44.

Harrington, H. J. 2011. Streamlined Process Improvement. New York: McGraw-Hill.

Ha-Vikström, T., and J. Takala. 2016a. 'Knowledge Management and Analytical Modelling for Transformational Leadership Profiles in a Multinational Company.' In Successes and Failures of Knowledge Management, edited by J. Liebowithz, 151-74. Amsterdam: Elsevier.

Ha-Vikström, T., and J. Takala. 2016b. 'Measuring Transformational Leadership Profiles: An empirical study across 21 nations in a multinational company.' Theoretical Issues in Ergonomics Science. http://www.tandfonline.com/doi/abs/10.1080/1463922X.2016 .1239780

Ha-Vikström, T., and J. Takala. 2016c. 'Do Cultures, Genders, Education, Working Experience or Financial Status Influence the Effectiveness of Transformational Leaders?' Theoretical Issues in Ergonomics Science. http://www.tandfonline.com/doi/abs/10.1080/1463922X.2016 .1243275 
Hemphill, J. K., 1950. 'Relations between the Size of the Group and the Behavior of "superior" leaders.' The Journal of Social Psychology 32 (1): 11-22.

Hill, L. A. 2003. Becoming a Manager: How New Managers Master the Challenges of Leadership. Boston, MA: Harvard Business Press.

Hitt, M. A., P. W. Beamish, S. E. Jackson, and J. E. Mathieu. 2007. 'Building Theoretical and Empirical Bridges across Levels: Multilevel Research in Management.' Academy of Management Journal 50:138599.

House, R. J. 1971. 'Path-Goal Theory of Leadership Effectiveness.' $A d-$ minstrative Science Quarterly 16 (3): 321-39.

Indvik, J., and M. A. Fitzpatrick. 1986. 'Perceptions of Inclusion, Affiliation, and Control in Five Interpersonal Relationships.' Communication Quarterly 34 (1): 1-13.

Jackson, B., and K. Parry. 2011. A Very Short Fairly Interesting and Reasonably Cheap Book about Studying Leadership. London: Sage.

Jensen, M. C. 1978. 'Some Anomalous Evidence Regarding Market Efficiency.' Journal of Financial Economics 6 (2): 95-101.

Johannsen, M. 2012. 'The Importance of Choosing the Right Leadership Style.' https://www.legacee.com/types-of-leadership-styles/\# .WQ3iwXJMRaQ

Katz, D., N. Maccoby, and N. C. Morse. 1950. Productivity, Supervision, and Morale in an Office Situation. Ann Arbor, MI: University of Michigan.

Kluckhohn, F. R., and F. L. Strodtbeck. 1961. Variations in Value Orientations. Evanston, IL: Row and Peterson.

Jin, S., Seo, M. G., and D. L. Shapiro. 2016. 'Do Happy Leaders Lead Better? Affective and Attitudinal Antecedents of Transformational Leadership.' The Leadership Quarterly 27 (1): 64-84.

Kazmi, S. A. Z. 2016. 'Fusing Strategic Thinking and Transformational Leadership to Harness new Product Development Team Dynamics for Innovation.' PhD dissertation, University of Vaasa, Vaasa.

Larsson, J., and S. Vinberg. 2010. 'Leadership Behaviour in Successful Organisations: Universal or Situation-Dependent?' Total Quality Management 21 (3): 317-34.

Lincoln, Y. S., and E. G. Guba. 1985. Naturalistic Inquiry. Beverly Hills, cA: Sage.

Lincoln, Y. S., S. A. Lynham, and E. G. Guba. 2011. 'Paradigmatic Controversies, Contradictions, and Emerging Confluences, Revisited.' The Sage Handbook of Qualitative Research, edited by N. K. Denzin and Y. S. Lincoln, 97-128. London: Sage.

MacKenzie, S. B., P. M. Podsakoff, and G. A. Rich. 2001. 'Transformational and Transactional Leadership and Salesperson Performance.' Journal of the Academy of Marketing Science 29:115-34. 
Maclean, M., C. Harvey, and R. Chia. 2012. 'Sensemaking, Storytelling and the Legitimization of Elite Business Careers.' Human Relations 65 (1): $17-40$.

Mann, F. C. 1965. 'Toward an Understanding of the Leadership Role in Formal Organizations.' In Leadership and Productivity, edited by R. Dublin, 68-103. San Francisco, CA: Chandler.

Maxwell, J. A. 2012. Qualitative Research Design: An Interactive Approach. London: Sage.

Merriam, S. B., and E. J. Tisdell. 2015. Qualitative Research: A Guide to Design and Implementation. Hoboken, nJ: Wiley.

Miles, M. B., and A. M. Huberman. 1994. Qualitative Data Analysis. Thousands Oaks, cA: Sage.

Mingers, J. 2001. 'Embodying Information Systems: The Contribution of Phenomenology.' Information and Organization 11 (2): 103-28.

Misumi, J., and M. F. Peterson. 1985. The Behavioral Science of Leadership: An Interdisciplinary Japanese Research Program. Ann Arbor, MI: The University of Michigan Press.

Ouchi, W. G., 1981. 'Organizational Paradigms: A Commentary on Japanese Management and Theory Z Organizations.' Organizational Dynamics 9 (4): 36-43.

Padgett, D. K. 2016. Qualitative Methods in Social Work Research. London: Sage.

Payne, S. C., S. S. Youngcourt, and J. M. Beaubien. 2007. 'A Meta-Analytic Examination of the Goal Orientation Nomological Net.' Journal of Applied Psychology 92 (1): 128-50.

Podsakoff, P. M., S. B. MacKenzie, J. Y. Lee, and N. P. Podsakoff. 2003. 'Common Method Biases in Behavioral Research: A Critical Review of the Literature and Recommended Remedies.' Journal of Applied Psychology 88 (5): 879-903.

Prichard, S. 2016. '5 Ways to Stop Reviewing History and Create the Future.' https://leadershipfreak.blog/2016/o8/o4/5-ways-to-stop -reviewing-history-and-create-the-future/

Rao, S. 2010. Happiness at Work. New York: McGraw-Hill.

Reddin, W. J. 1977. 'An Integration of Leader-Behavior Typologies.' Group \& Organization Studies 2 (3): 282-95.

Roberts, G. C., D. C. Treasure, and D. E. Conroy. 2007. 'Understanding the Dynamics of Motivation in Sport and Physical Activity: An Achievement Goal Interpretation.' Handbook of Sport Psychology, 3rd ed., edited by by G. Tenenbaum and R. C. Eklund, 1-30. Hoboken, NJ: Wiley.

Saldaña, J. 2015. The Coding Manual for Qualitative Researchers. London: Sage.

Seidman, I. 2013. Interviewing as Qualitative Research: A Guide for Researchers in Education and the Social Sciences. New York: Teachers College Press. 
Shenhar, A. J. 1993. 'From Low- to High-Tech Project Management.' R\&D Management 23 (3): 199-214.

Stephens-Craig, D., M. Kuofie, and R. Dool. 2015. 'Perception of Introverted Leaders by Mid to High-Level Leaders.' Journal of Marketing and Management 6 (1): 62-75.

Stogdill, R. M. 1963. Manual for the Leader Behavior Description Questionnaire. Columbus, он: The Ohio State University.

Strauss, A., and J. Corbin. 1998. Basics of Qualitative Research Techniques. London: Sage.

Thurmond, V. A. 2001. 'The Point of Triangulation.' Journal of Nursing Scholarship 33 (3): 253-8.

Ulrich, D., J. Zenger, and N. Smallwood. 2013. Results-Based Leadership. Boston, Massachusetts: Harvard Business School Press.

Venkatesh, V., S. A. Brown, and H. Bala. 2013. 'Bridging the QualitativeQuantitative Divide: Guidelines for Conducting Mixed Methods Research in Information Systems.' MIs Quarterly 37 (1): 21-54.

Wooden, J., and S. Jamison. 2009. Coach Wooden's Leadership Game Plan for Success: 12 Lessons for Extraordinary Performance and Personal Excellence. New York: McGraw-Hill.

Yukl, G. A. 2002. Leadership in Organizations. Upper Saddle River, NJ: Prentice Hall.

Zaccardi, M., C. Howard, and O. Schnusenberg. 2012. 'Student Preparation and Personality Traits in the Job Market.' Academy of Educational Leadership Journal 16: 35-53.

Zaleznik, A. 1977. 'Managers and Leaders: Are They Different?' Harvard Business Review 55 (3): 67-78. 